\title{
LABELING OF Salmonella typhymurium WITH IODINE-131 TO STUDY PHAGOCYTIC FUNCTION IN RATS.
}

\author{
Maria K. SATO(1), Aldo J. RODRIGUES JUNIOR(2) \& Edwaldo E. CAMARGO(1)
}

\begin{abstract}
SUMMARY
The present study describes a method for labeling Salmonella typhymurium with iodine 131 to evaluate both the morphological and the functional characteristics of the reticulo-endothelial system.

A suspension containing $2 \times 10^{9}$ bacteria per $\mathrm{ml}$ was labeled with carrier free $\mathrm{Na}^{131} \mathrm{I}$ without reductor, with a labeling yield of $46.5 \pm 3 \%$ and $3.5 \pm 1.3 \%$ of free Iodine-131.

The biodistribution of the labeled bacteria in rats was studied with a large field. of-view scintillation camera equiped with a pinhole collimator. Whole body images were obtained 15 and 30 minutes after in travenous injection of the labeled microorga nisms. Images showed accumulation of bacteria in the liver and both normal and transplanted spleens of the animals. Autoradiographs of liver and spleen demonstrated labeled bacteria within the cells of the reticulo-endothelial system.

The method described is easy to perform, has a good labeling yield and allows the functional evaluation of the reticulo-monophagocytic system, including transplanted spleens.
\end{abstract}

KEY WORDS: Salmonella typhymurium; Iodine-131: Transplanted spleen.

\section{INTRODUCTION}

Several microorganisms have been labeled with radioactive isotopes for studying the pha gocytic function of the reticulo-endothelial sys tem ( $R E S$ ), the mecanism involved in inflamma tory processes or the blood clearance of bacte ria ${ }^{1.2,4,6 .}$.

Although these phenomena can be studied with non-radioactive colloidal particles, by using labeled bacteria deposition is prevented.
This investigation describes a labeling pro cedure for Salmonella typhymurium with iodi ne-131 to study the phagocytic function of the RES.

\section{MATERIAL AND METHODS}

\section{Preparation of Bacteria}

The microorganisms, grown on simple agar medium, were obtained from the Bacteriology

(1) Centro de Medicina Nuclear, Complementar do Departamento de Radiologia da Faculdade de Medicina da Universidade de Sào Paulo. Săo Paulo, SP. Brasil.

(2) Disciplina de Cururgia Geral. Faculdade de Medicina da Universidade de Sāo Paulo. Sāo Paulo. SP. Brasil.

Address for correspondence: Dra. Maria Kasue Sato. Centro de Medicina Nuclear da Universidade de Sào Paulo. Caixa Postal 22022. CEP 01499 Sào Paulo, SP, Brasil 
KATO M. K RODRIGUES JUNIOR. A. \& \& CAMARGO, E. E. ... Labeling of Saimonella typhymurium with IOdine 131 3) study phapneytic function in rats. Rev. Inst. Med, frop. S. Malu, 31(3): 135138, 1989.

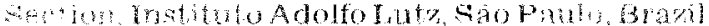

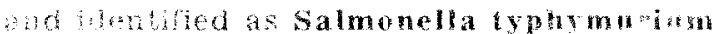
$4,12.3: 2$ strain. Ar aliquot of the bacteria was scraved tom the agar plate and transferred to andher simple ager plate and incubated to is on nus at 37 c The bacteria were thenburno

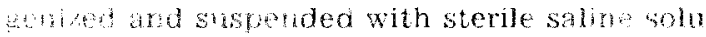
hati and dinted to a final concentration at 2

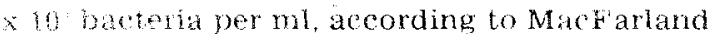
bramm sulfate standards.

\section{Lathething Technique?}

A modification of the method of GREEN WoOD et $a l^{3}$, was used for labeling the microor ganisms. Three ml of the final Salmonella typhy. marium suspension were transferred to a conic tube and centrifuged at $1.000 \mathrm{x}$ g for 10 minutes Tire supernatant was discarded and to bacterial pelle were added $0.2 \mathrm{ml}$ of phosphate buffer $\mathrm{pH}$ $7.3,0010.02 \mathrm{ml}$ of carrier free $\mathrm{Na}^{131} \mathrm{I}(222.0 \mathrm{MBq}$ $\mathrm{mg}$ or $6.0 \mathrm{Ci} \mathrm{mg}$ ) and $2.0 \mathrm{mg}$ of chloramine $\mathrm{T}$ Merek1. The suspension was gently mixed and allowed to reaction at room temperature for 15 minutes. The reaction was then stopped with $4.0 \mathrm{mg}$ of sodium metabisulphite. The suspen sion was again centrifuged at $1,000 \times \mathrm{g}$ for 10 minutes and the supernatant discarded. The bacteria were resuspended in $5.0 \mathrm{ml}$ of saline and the protein free iodide removed by centrifuga tion with three consecutive saline washes After the third wash, the bacteria were transferred to another tube and the washing procedure repes. ted twice with $2.0 \mathrm{ml}$ of saline solution. Racterial viability was not studied and the tracer conta minant amount was carried by free ${ }^{1 / 31} I$ quantifi cation in ascending chromatography.

\section{Biodistribution}

The adequacy of labeled bacteria for stu dying the phagocytic function of the RES was evaluated in 14 normal Wistar rats (183.259 $\mathrm{g}$ ). The irvestigation was then extended to inchude the phagocytic function of transplanted spleen of 27 Wistar rats $(182-243 \mathrm{~g}$ ). Each animal was injected with $70 \mu \mathrm{Ci}(2.59 \mathrm{MBq})$ of bacterial sus pension into the tail vein 15 to 30 minutes prior to whole body imaging ${ }^{5}$. Images with 50,000 counts were obtained with a large-field-of-view scintillation camera equiped with a pinhole collimator
Twelt hours after the injection the animals xusticed and the live and spleen removed for histologic and antoradiographic studies.

\section{RESULTS}

The labeling yield of 10 consecutive experi ments averaged $46.5 \neq 3 \%$ and the amount of free radioactive iodide $3.5 \pm 1.3 \%$. Whole body imaging demonstrated selective uptake of Salmonella typhymurium ${ }^{13 i}$ I by the liver and spleen (Fig. 1).

Autoradiographs of the liver showed silver granules precipitation over the Kupffer cells, which indicated phagory tosis of the bacteria. Similarly, autoradiographs of both normal and transplanted spleens showed silver granules pre cipitation over the mononuclear cells of the red pulp, indicative of bacterial phagocytosis (Figs. 2,3 and 4)

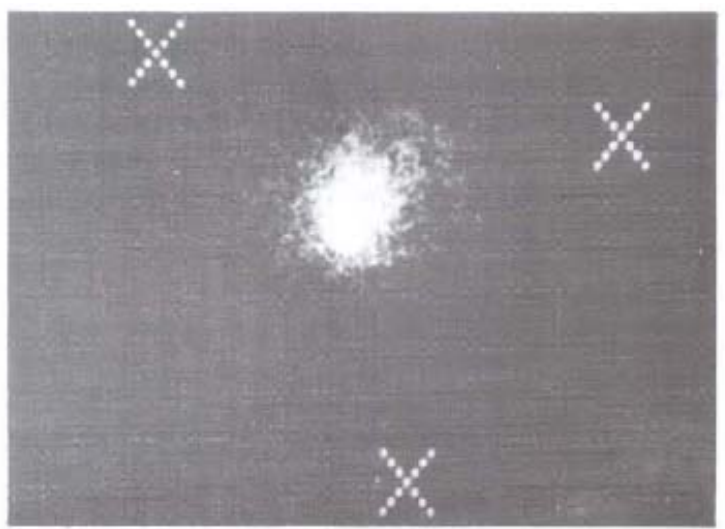

Fig. 1 - Whole body imaging of a normal rat 15 minutes after intravenous injection of Salmonella ty phymurium- ${ }^{13} I$. The radioactive area represents uptake of the bacteria by the liver and spleen.

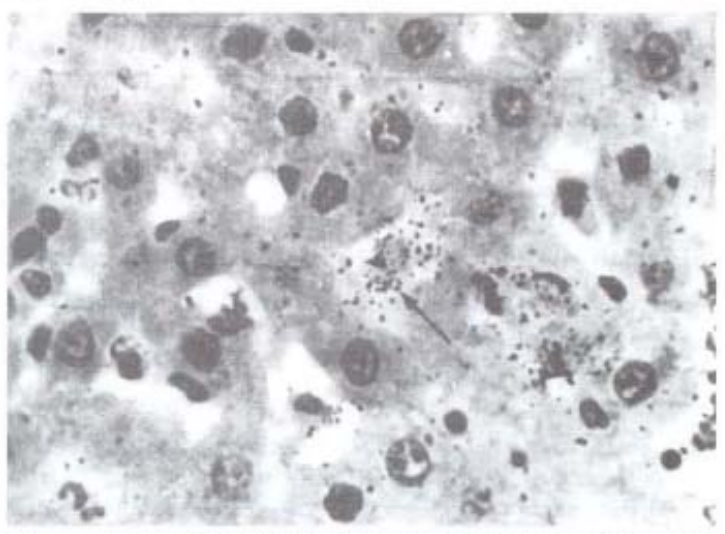

Fig. 2 - Autoradiogram of a rat liver showing labeled bacteria (arrow) in the cytoplasm of the Kupffer cells $(1,200 \mathrm{X}$ ). 
KATO, M. K.; RODRIGUES JUNIOR, A. J.\& CAMARGO. E. E. - Labeling of Salmonella typhymurium with Iodine 131 to study phagocytic function in rats. Rev. Inst. Med. trop. S. Paulo, 31(3): 135-138, 1989.

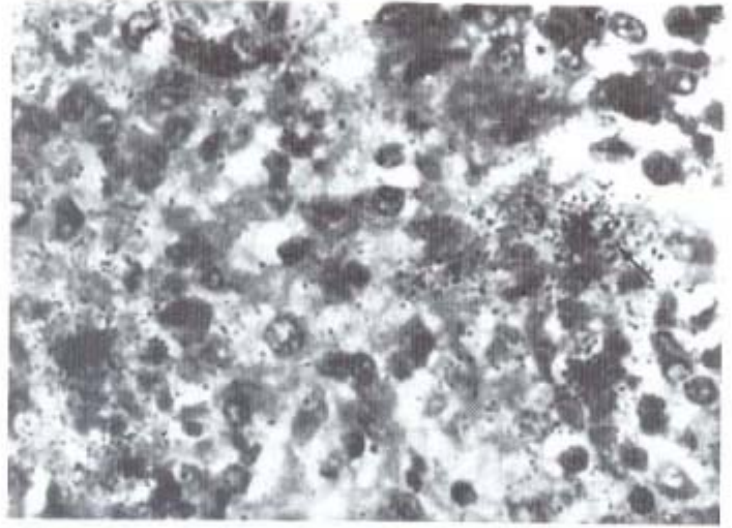

Fig. 3 - Autoradiogram of a rat spleen showing labeled bacte ria (arrow) in the cytoplasm of reticulo-monophagocytic sys tem cells $(1,200 \mathrm{X}$ ).

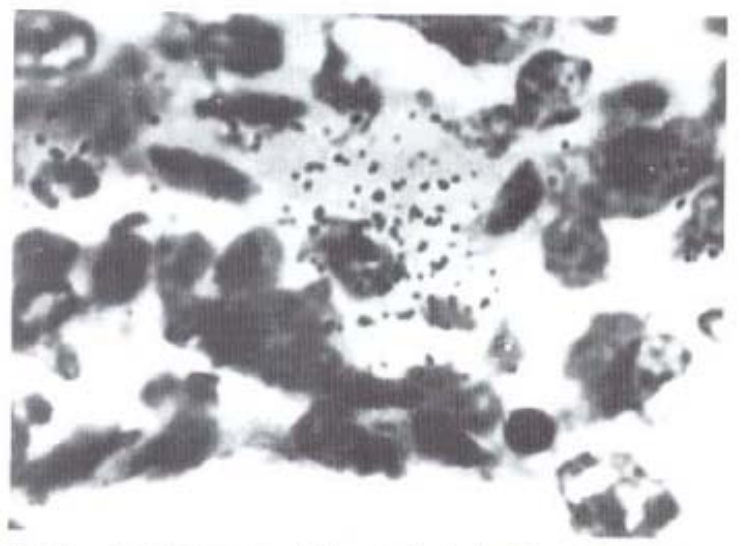

Fig. 4-Autoradiogram of a transplanted spleen showing labeled bacteria in the cytoplasm of the reticulo-monophagoeytic system cells $13.000 \mathrm{X}$ ).

\section{DISCUSSION}

Because of its tropism to splenic tissue and the ease of maintenance in the laboratory, Salmonella typhymurium is the microorganism of choice for assessment of the phagocytic function of the transplanted spleen.

It was noticed, in this investigation, that when the bacteria were not freshly grown prior to labeling the radiochemical yield of the procedure was very low, increasing the amount of free iodide and therefore making the microorga nisms unsuitable for use.

To improve the radiochemical yield, a few modifications were introduced in the chloramine
$\mathrm{T}$ iodation method ${ }^{6}$. Iodide-131 incorporation into bacterial protein is strongly dependent upon the reaction volume. Therefore, the reaction vo lume was reduced to a minimum by centrifugation of the bacterial suspension and addition of chloramine $\mathrm{T}$ in the crystalline form, with no dissolution, to the bacterial pellet. Since chloramine $\mathrm{T}$ is a strong oxidant agent, an excess of microorganisms was used to minimize cell da mage. The pellet was washed with saline solu tion only, to minimize bacterial loss. With these modifications the microorganisms could be used for up to 24 hours after labeling.

Since the description of the hazards in over whelming post splenectomy syndrome there ha ve been an increased attention in splenic conser vative maneuvers mainly directed to splenic trauma.

In this way, the omental pouch splenic hete rotopic autotransplant has been reported. Mean while some controversies do exist on the filtering hability of these regenerated splenic tissue.

\section{RESUMO}

Marcação de Salmonella typhymurium com iodo-131 para estudo da funçāo fagocitária em ratos.

O presente trabalho descreve um método para marcação de Salmonella typhymurium com iodo 131, útil para avaliar tanto os aspectos morfológicos como funcionais do sistema retícu. lo-endotelial.

Uma suspensão contendo $2 \times 10^{9}$ bactérias por $\mathrm{ml}$ foi marcada com $\mathrm{Na}^{131} \mathrm{I}$ livre de carregador e de redutor, resultando em um rendimento de marcação de $46,5 \pm 3 \%$ e $3,5 \pm 1,3 \%$ de iodeto-131 livre.

Estudou se a biodistribuiçāo das bactérias marcadas em ratos, obtendo-se imagens de cor. po total aos 15 e 30 minutos após injeção em uma câmara de cintilação de campo de visāo amplo, equipada com um colimador "pinhole". As imagens mostraram captação das bactérias pelo fígado e pelo baço normal ou transplantado, dos animais estudados. Os cortes autoradiográficos de baço e fígado mostraram bactérias mar- 
KATO, M. K.: RODRIGUES JUNIOR, A. J. \& CAMARGO, E. E. - Labeling of Salmonclla typhymurium with Iodine 131 to study phagocytic function in rats. Rev. Inst. Med. trop. S. Paulo, 31(3): 135138.1989.

cadas dentro das células do sistema retículo-en dotelial.

O método de marcaçáo da Salmonella typhymurium com iodo-131 se mostrou de facil execução com rendimento adequado, possibili tando a avaliaçāo funcional de órgảos do sistema retículo-monofagocitário como o baço trans plantado.

\section{ACKNOWLEDGEMENT}

The authors are indebted to Gilde C. D. He mielevski for her assistance in the preparation of the references cited

\section{REFERENCES}

1. HETTIN, K.: ALLEN, O'C. M.: GERDING, N D.: HORS TRENN. L \& SHAFER. R. ... In 111 Psedudomonas aeruginosa: a simple mothod of labeling live bacteria with a fama emitting radioisotope Europ. J. Nucl. Med., I?: 277279,1986
2. BIOZZI, G.; HOWWARD, J. G.: HALPERN, B. N.: STIF FEL, C. \& MOUTON, D. - The kinetics of blood elearance of isotopically labeled Salmonella enteritidis by the reti culoendothelial system in miec. Immunology, 3: 74.89 1960 .

3. GREENWOOD. F. C. HUNTER, W. M. \& GLOVER, J S. The preparation of ${ }^{131}$ I labeled human growth homo ne of high specific radioactivity. Biochem. J., 89: 114123 1963

4. MELBY. K. \& MIDVEDT, T, ... Brief report; a study of the climination phase of phagocytosis of ${ }^{*} \mathrm{P}$ labeled Escherichia coli by human polymorphonucleas cells. Acta path. microbiol seand., 89: $37,39.1981$

5. RODRIGUES Jr. A J Auto transplante heterotopico do baco: estudo experimental. Sáo Paulo. 1985 'Tese de Doutoranente Faculdadede Medicinada Universidade de' Sao Paulos.

6. SPECTOR, W. G.; REICHHELD, N. \& RYAN, G. B. Degradation of granuloma inducing microorganisms by macrophages. J. Path., 101: 339 354, 1970.

Recebido para publicacao em 5488 